\title{
КРИМІНАЛЬНА ВІДПОВІДАЛЬНІСТЬ ЗА НЕЗАКОННИЙ ОБІГ ЗБРОЇ: ІСТОРИЧНІ ВИТОКИ СТАНОВЛЕННЯ ТА РЕФОРМУВАННЯ ІНСТИТУТУ
}

Меркулова В. О., Павленко Л. М.

\begin{abstract}
у статmі на підставі історичного системно-порівняльного дослідження правових джерел загального та кримінально-правового характеру, що застосовувались на території України за часів Київської Русі, Галицько-Волинського князівства, часів чинності законодавства Російської імперії на території Східної України, визначено витоки становлення та напрями реформування кримінальної відповідальності за незаконний обіг зброї, бойових припасів та вибухових речовин. Наступність законодавства щодо розглядуваної сфери в Україні з пострадянського часу й дотепер досліджено на прикладі особливостей Кримінальних кодексів України 1922, 1927, 1960, 2001 рр.
\end{abstract}

На підставі історико-правового аналізу нормативних актів, що регламентують незаконні діі зі зброєю, пропонується виокремити такі історичні emanu. X-XVI столітmя - етап становлення криміналізації діянь, пов'язаних із використанням зброї (різних їі різновидів), діянь, предметом посягання яких $\epsilon$ зброя. XVII - початок XX столітmя - eman формування кримінального законодавства щодо незаконного поводження зі зброєю та вибухівкою, переробки та інших дій, спрямованих на вдосконалення їхніх властивостей. 1920-1991 роки (переважно часи входження України до (РСР) - eman розвитку кримінального законодавства в частині уточнення дефініцій та санкцій щодо різних дій по відношенню до зброї, боєприпасів, вибухівки змін їхніх властивостей. 31991 p. domenep - період остаточної трансформації та формування кримінального законодавства України у сфері незаконного обігу зброї, бойових припасів, вибухових речовин на тлі основних напрямів становлення правової незалежності України та обговорення можливостей легалізації обігу окремих видів зброї. Законодавець все більшу увагу приділяє криміналізаціі тих діянь, які пов'язані зі зміною властивостей вогнепальної зброї та бойових припасів.

Доведено, що за доволі тривалий час мали місце різні підходи ставлення до визначення головних ознак суспільно небезпечної поведінки, яка посягає на громадський порядок та громадську безпеку, предметом якої є зброя, бойові припаси та вибухові речовини. Історичний шлях відтворює визначення багато-

(С) Меркулова В. О., Павленко Л. М., 2020 чисельних норм, змістом яких є одна або дві дії, до визначення альтернативної поведінки, яка фіксується у двох або трьох нормах.

Ключові слова: бойові припаси, вибухові речовини, зброя, кримінальна відповідальність, незаконний обіг, історична періодизація, реформування законодавства.

Merkulova V. O., Pavlenko L. M. Criminal liability for illicit arms trafficking: historical origins of the formation and reform of the institution

The article, based on a historical system-comparative study of legal sources of general and criminal law, used in Ukraine during the Kievan Rus, Galicia-Volyn principality, the legislation of the Russian Empire in Eastern Ukraine identifies the origins and directions of reform criminal liability for illicit trafficking in weapons, ammunition and explosives. The continuity of the legislation on this area in Ukraine from post-Soviet times to the present day has been studied on the example of the peculiarities of the Criminal Codes of Ukraine of 1922, 1927, 1960, 2001.

On the basis of the historical and legal analysis of the normative acts regulating illegal actions with the weapon it is offered to allocate the following historical stages. X-XVI century - the stage of criminalization of acts related to the use of weapons (its various types); acts, the subject of encroachment of which is a weapon. XVII - early XX century - the stage of formation of criminal legislation on the illegal handling of weapons and explosives, processing and other actions aimed at improving their properties. 1920-1991 (mostly the times of Ukraine's accession to the USSR) - a stage in the development of criminal law in terms of clarifying the definitions and sanctions for various actions in relation to weapons, ammunition, explosives changes in their properties. From 1991 to the present - the period of final transformation and formation of criminal legislation of Ukraine in the field of illicit trafficking in weapons, ammunition, explosives against the background of the main directions of legal independence of Ukraine and discussion of legalization of certain weapons. The legislator is paying more and more attention to the criminalization of those acts that are associated with changes in the properties of firearms and ammunition. 
It has been proven that for a long time there have been different approaches to identifying the main features of socially dangerous behavior that encroaches on public order and public safety, the subject of which is weapons, ammunition and explosives. The historical path reproduces the definition of numerous norms, the content of which is one or two actions, to the definition of alternative behavior, which is fixed in two or three norms.

Key words: ammunition, explosives, weapons, criminal liability, illicit trafficking, historical periodization, legislative reform.

Постановка проблеми та іï актуальність. Загальновизнаним $\epsilon$ те, що в дослідженні будьякого кримінально-правового інституту найчастіше використовується історико-правовий метод дослідження. Чинників, які зумовлюють важливість цього методу дослідження, декілька. По-перше, це дозволяє дослідити об'єкт у контексті історії його розвитку, а отже, здійснити ретроспективний аналіз певних соціально-правових явищ, дослідити витоки становлення та особливості розвитку досліджуваних кримінально-правових інституцій, а відповідно, специфічність змісту конкретних нормативно-правових приписів, актів судового тлумачення різних періодів історії України. По-друге, саме цей метод дозволяє відтворити існуючий (як на той час) погляд суспільства на ступінь суспільної небезпечності діяння, пов'язаного з обігом зброї (як вогнепальної, так i холодної), а відповідно, на доцільний обсяг караності такого діяння.

Соціальні та правові традиції суспільства, моральні цінності, а відповідно, критерії відмежування кримінально-протиправного від інших видів правопорушень, межі мінімально необхідного покарання щодо винної особи відтворюються в цілій низці правових джерел, які діяли на території України в різні періоди іiі історії. Саме історичне системно-правове дослідження змісту окремих правових норм правових джерел часів Київської Русі, Галицько-Волинського князівства, Великого князівства Литовського, часів дії правових актів Російської та Австро-Угорської імперії, особливостей криміналізації відповідних діянь за пострадянського часу тощо дозволить не лише визначитися 3 витоками кримінально-правової регламентації досліджуваної сфери, але й наступністю кримінального законодавства, із проблемами, які можна віднести до сталих, таких, що безпосередньо (або ж опосередковано) впливали на зміни в законодавстві надалі й практично відтворюються в суперечностях чинного кримінального законодавства.
Аналіз останніх досліджень i публікацій. Якщо керуватися доктринальними джерелами, які використані нами під час дослідження вибраної теми історично-порівняльного характеру, слід виокремити певні узагальнюючі ознаки цих джерел, в яких аналізу піддаються саме історичні аспекти становлення кримінальної відповідальності за незаконний обіг зброї. Вибрана нами проблема дослідження $\epsilon$ складовою частиною багатьох робіт, присвячених історії держави і права України (Ф.Й. Рогожин, М.М. Страхов, В.Д. Гончаренко). 3 історичної точки зору доволі цікавими $\epsilon$ коментарі, які надаються М.С. Таганцевим стосовно головних кримінально-правових джерел XIX - початку XX століть (Укладення про покарання кримінальні та виправні), що досить тривалий час діяли на сході України. Використовувалися роботи, присвячені загальним аспектам становлення відповідальності за незаконний обіг зброї (починаючи з X ст. до початку XX століття) без виокремлення безпосередньо різновидів такої поведінки (Є.В. Георгиевский, О.О. Задоя, Л.О. Сошина). Сучасним проблемам попередження незаконного обігу зброї присвячені роботи А.Є. Шалагіна, М.Ю Гребенкіна. Окремі вчені вибрали предметом дослідження витоки становлення й напрями реформування кримінальної відповідальності за конкретні незаконні дії зі зброєю, зокрема: за недбале зберігання вогнепальної зброї або бойових припасів (С.Б. Боровинський), за незаконне виготовлення зброї (М.М. Мусаєв), за торгівлю і транспортування мисливської зброї (О. Проців). Питання порівняльного аналізу змісту та сутності кримінально-правових положень чинного та попереднього Кримінальних кодексів щодо незаконного поводження зі зброєю, бойовими припасами та вибуховими речовинами $\epsilon$ предметом досліджень В.О. Меркулової.

Мета статті. Досліджуючи зміст та сутність окремих правових положень, що стосуються особливостей історичного підходу до визначення правил обігу зброї, законності та протиправності конкретної дії, відстежуючи певні закономірності та взаємозв'язки в законодавчих визначеннях, маємо на меті визначитися умовно з певною періодизацією становлення та розвитку кримінальноправового регулювання сфери обігу зброї, відслідкувати ті специфічні ознаки (критерії), які й зумовили наше рішення про доцільність цієї періодизації та типовість кожного окремого етапу.

Виклад основного матеріалу. Особливості правового регулювання розглядуваної сфери за часів Київської Русі відтворюються в такому джерелі права, як Руська Правда. Історія знає 
три її редакції: «Руська Правда» XI століття, яка складалася із Правди Ярослава, Правди Ярославичей, Статуту Ярославичей; Руська Правда XII ст. - періоду Володимира Мономаха; Коротка редакція Руської ПравдиXV-XVII століть [6, с. 70-74]. У даній давньослов'янській пам'ятці кримінального законодавства, що відтворювала особливості Давньоруської держави, як, до речі, і в інших джерелах права того часу (Псковській та Новгородській судній грамоті), громадська безпека ще не розглядається як самостійний об'єкт кримінально-правової охорони. У них містилися лише приписи, відповідно до яких кримінально-караними визнавалися діяння, які завдавали шкоди майновим і особистим інтересам громадян й одночасно порушували громадський спокій, порядок функціонування різних інституцій (церкви, суду тощо). Типовим прикладом цього $\epsilon$ зміст відповідних норм, які містилися в Короткій редакції Руської правди (ст. ст. 3, 4, 13) - пам'ятці найбільш пізнього періоду, в якій термін «зброя» (різні ії конкретні види) використовується в законодавстві для характеристики як конструктивної, так і кваліфікуючої ознаки діяння. Зокрема, встановлюється відповідальність (штраф) за крадіжку зброї, значно посилюється відповідальність (більш значний розмір штрафу) за побої, спричинені палкою, жердиною, тильною частиною меча або піхвами меча, що розглядалося як дії, які $\epsilon$ особливо образливими для потерпілого. Не містив системи норм про заборону обігу зброї і Галицький літопис (1383 р.). Проте особливістю $€$ те, що в ньому вже існують перші згадки про вогнепальну зброю «армати» $[4$, с. $63 ; 1$, с. 413; 12].

Визначення особливостей нормативно-правового регулювання (як загального, так і кримінально-правового характеру) сфери обігу зброї на території України часів дії нормативно-правових актів Російської та Австро-Угорської імперій (XVII - початок XX століття) передбачає здійснення системно-правового аналізу правових актів певного історичного етапу. Слід зазначити, що регіональні особливості правового регулювання на східноукраїнських та західноукраїнських землях саме пов'язані зі специфічністю становлення та розвитку сфери обігу зброї в цих двох імперіях. У даному випадку пропонуємо розглянути питання щодо особливостей розвитку відповідного кримінального законодавства Російської імперії у XVII початку XX столітті.

На увагу заслуговують Царський Указ від 25 жовтня 1682 р., Указ «Про покарання за стрілянину з рушниць і кидання ракет у місті» (1699р.).
Саме ці правові акти свідчать про те, що в російському цивільному законодавстві поступово починають формуватися обмеження, які стосуються цивільного обігу зброї: існувала заборона носіння зброї особами, які не виконували відповідних обов'язків з охорони правопорядку. Проте відповідальність мала настати лише в разі сварок, поєдинків, використання грубих слів, безпідставної стрілянини в містах кулями та пижами тощо [2, с. 104; 12].

Не менше значення мало Соборне укладення 1649 р., яке відносять до перших законодавчих актів у Московії про незаконний обіг зброї: вважається, що саме в цьому акті (у ст. ст. 6 та 7 розділу III) згадується вперше про вогнепальну зброю (пищали). У Соборному укладенні встановлювалася відповідальність за недозволене носіння, оголення або застосування зброї при царському дворі або в присутності самого царя із встановленням доволі суворого покарання - смертної кари. Набувають подальшого уточнення положення щодо впливу на ступінь небезпечності діяння факту використання зброї як знаряддя злочину, так і тих ситуацій, коли зброя $\epsilon$ предметом правопорушень [3; 11].

Проте найсуттєвішого розвитку законодавство Російської імперії про кримінальну відповідальність за незаконний обіг зброї зазнало у XVIII початку XX століть. Важливим $\epsilon$ те, що значна кількість правових положень, які впливали на порядок та умови обігу зброї, містилася як у правових актах суто кримінально-правового характеру - Укладенні про покарання кримінальні та виправні (редакції 1845, 1885 та 1903 років), так і в багаточисельних правових документах, що регулювали різні сфери тогочасної життєдіяльності. Бурхливий розвиток суспільства, доволі важливі та складні завдання, які вирішувала держава в боротьбі із зовнішнім ворогом, вимагали більш жорсткої дисципліни, формування професійної армії, мобілізації можливостей цивільного населення тощо. Це не могло не вплинути на пришвидшення формування системи правових положень, які стосувалися обмежень в обігу зброї.

Якщо підійти узагальнено до аналізу та зіставлення змісту відповідних положень, які містилися в Указі Петра I «Про заборону носіння та продажу гострих ножів» (1700р.), в Артикулі військовому (1715 р.), Морському статуті (1720р.) тощо, то слід звернути увагу на таке. Започатковувався процес державного контролю за обігом зброї, який надалі лише посилювався. Заборонялося виготовлення, продаж та носіння холод- 


\section{Актуальні проблеми \\ історико-правової науки}

ної зброї (схожої з кинджалом). Зазначені акти могли містити дисциплінарні, адміністративні та кримінальні норми. Зокрема, в артикулах 56-59 Глави VI Артикула військового йшлося про покарання солдата за неналежний догляд за зброєю, втрату зброї, іiі викидання, псування, поломку, програш, продаж, закладення, придбання [3; 10].

Надалі складником посилення державного контролю за обігом зброї стала правова практика формулювання спеціальних правил користування (зберігання) зброї приватними особами, положень та правил щодо використання зброї в державних органах. Митний статут, Лісовий статут, Статут про засланців, Положення про Корчемної сторожі тощо містили саме такі норми. Існував окремий Військовий статут про покарання (1868р.), який передбачав відповідальність за військові злочини, які вчинялися із застосуванням зброї [19].

Що стосується безпосередньо правових актів суто кримінально-правового характеру, на особливу увагу заслуговує аналіз змісту положень Укладення про покарання кримінальні та виправні редакції 1845, 1885 та 1903 років. На підставі безпосереднього аналізу правових норм, які містяться в Укладенні, та врахування результатів наукових досліджень учених у цьому питанні (С.Б Боровинського, М.М. Мусаєва, С.А. Нєвского, Л.А. Сошиної) маємо визначитися з певними сутнісними ознаками різних редакцій Укладення, сформувати власне бачення напрямів реформування кримінального законодавства того часу в частині регулювання обігу зброї.

Перша редакція Укладення була створена на основі Зводу законів Російської імперії і далі набувала нової редакції та вдосконалення. Цей акт діяв на території Російської імперії практично до жовтня 1917 року. На перший погляд у цих кримінально-правових джерелах не виокремлювалося самостійного розділу (або ж глави), де би були зосереджені норми про відповідальність за увесь комплекс діянь, пов'язаних із незаконним обігом зброї (бойових припасів, вибухових речовин). Проте Укладення в різних розділах, главах, відділеннях могли містити досить велику кількість норм про діяння, які ми можемо віднести до розглядуваної сфери кримінально-протиправного конфлікту.

Стосовно особливостей різних редакцій Укладення щодо визначення ознак кримінально протиправного діяння виявляється таке. В Укладенні про покарання кримінальні та виправні (1845р.) відповідальність за протиправне поводження зі зброєю, боєприпасами і вибуховими речовинами передбачена ст. ст. 1241-1247, 1249 відділення дев'ятого «Про протизаконне виготовлення і зберігання зброї або пороху для захисту особистої безпеки» глави третьої «Про порушення громадського спокою, порядку» розділу VII. Диспозиції цих норм містять ознаки правопорушень, які полягають: у незаконному виготовленні зброї, пороху, бомб, гранат чи снарядів до артилерійських знарядь (ст. 1241); незаконному зберіганні зброї або пороху в більших, ніж дозволено, розмірах (ст. 1242); у збереженні забороненої або у великій кількості зброї, пороху, боєприпасів до артилерійських знарядь з метою завдати шкоди державній безпеці (ст. 1243); у не донесенні відомостей про людину, яка принесла для ремонту заборонену законом зброю (ст. 1244); використанні вогнепальної зброї в місцях масового скупчення людей (ст. 1245); стрільби з луку в місцях масового скупчення людей (ст. 1246); зберіганні в домівках чи місцях можливого перебування людей зарядженої вогнепальної зброї (ст. 1247); перебуванні зі зброєю (особливо зарядженою) в заборонених місцях (ст. 1249).

Кваліфікуючою обтяжуючою ознакою щодо дій, передбачених у ст. ст. 1241 та 1242, є наявність спеціальної мети - підрив державної безпеки чи спокою. Якщо використання вогнепальної зброї та стрільба з луку призводили до настання тяжких наслідків (шкода здоров'ю, смерть), додатково застосовувалися ст. ст. 1937, 1965, які визначали відповідальність саме за ці наслідки. До того ж слід зазначити, що в окремій системі норм (ст. ст. 986-987) визначається відповідальність лише за порушення правил поводження зі зброєю, порохом, вибуховими речовинами, снарядами.

Із прийняттям Уставу (Cmamymy) про покарання, які накладаються мировими суддями (1864 р.), загальна кількість статей в Укладенні значно скоротилася, оскільки з нього було виключено норми, що передбачали відповідальність за малозначні діяння. Якщо звернутися до змісту статей глави десятої Статуту «Про проступки проти особистої безпеки», то побачимо, що окремі дії, відповідальність за які була передбачена ст. ст. 1247, 1249, перейшли в різновид проступків. Зокрема, це стосується зберігання чи носіння забороненої зброї; стрільби з вогнепальної зброї в заборонених місцях; зберігання пороху понад установлену кількість; порушення правил обережності зберігання зарядженої зброї тощо (ст. ст. 117, 118).

Кримінальне уложення 1903 року істотно відрізняється від попередніх законодавчих актів 
як техніко-юридичним викладом, так і змістом. Основна кількість норм, що передбачають відповідальність за незаконний обіг зброї і боєприпасів (ст. ст. 222-227, 230), містилася в Главі десятій Кримінального уложення «Про порушення постанов, що забезпечують громадську та особисту безпеку». Особливістю $є$ те, що розширюється перелік кримінально-караних дій у сфері обігу зброї, бойових припасів та вибухових речовин, виокремлюються як суспільно небезпечні нові діяння: незаконне зберігання вогнепальної зброї або снаряду за межами обладнаного для цього складу; зберігання пороху за межами складу в кількості понад тридцять футів; невиконання правил обладнання чи утримання складів вибухових речовин для потреб гірничозаводської чи соляної промисловості; створення небезпеки вибуху; незаконне виготовлення зброї та боєприпасів саморобним способом або ж у заводських умовах; відкриття без належного дозволу заводу для виготовлення вибухових речовин, вогнепальних боєприпасів; торгівля вибуховими речовинами i боєприпасами тощо. I водночас Кримінальне уложення не містило спеціальної норми про розкрадання зброї. Відповідальність за такі діяння наставала за статями про інші види злочинів (злодійство, розбій, вимагання) [1, с. 414; 8; 9; 11-14].

Відповідно, складником розглядуваного питання $\epsilon$ напрями та сутність реформування (удосконалення) вітчизняного кримінального законодавства за часів існування різних Кримінальних кодексів (далі - КК) України (1922, 1927, 1960, 2001 років).

На підставі системно-правового аналізу положень, що містилися в КК УРСР 1922 р., та тлумачення його окремих положень у доктрині права маємо визначитися з їхніми певними особливостями. 3 одного боку, перелік норм, що встановлювали кримінальну відповідальність за злочинне поводження зі зброєю, бойовими припасами та вибуховими речовинами, в даному кодексі (порівняно із правовими актами царської Росії) був значно коротшим. Проте, 3 іншого боку, позитивним $є$ те, що відповідна норма міститься у Главі, яка родовим об'єктом посягання вже чітко визначає, окрім іншого, громадську безпеку та публічний порядок. Зокрема в Главі VIII «Порушення правил, що охороняють народне здоров'я, громадську безпеку та публічний порядок», у ст. 220 КК встановлювалася відповідальність за зберігання вогнепальної зброї без відповідного дозволу. До того ж факт використання зброї розглядався як обтяжуюча обставина під час вчи- нення інших діянь. Так, зокрема, за перевищення влади із застосуванням зброї (ст. 106 КК УРСР) передбачалася вища міра покарання [15].

Зазначена Глава з відповідною назвою зберігається і в КК УРСР 1927 р. Проте законодавець визнав за необхідне значно поширити перелік діянь, які розглядалися як незаконні у сфері обігу вогнепальної зброї, вибухових речовин, снарядів тощо. Так була встановлена відповідальність за здавання на пошту заборонених для пересилання вибухових, легкозаймистих та їдких речовин, кислот (ст. 195 КК УРСР); за виготовлення, зберігання, купівлю, збут вибухових речовин, снарядів, вогнепальної зброї військового зразку без передбаченого дозволу (ст. 196 КК УРСР) [16]. Перші радянські кримінальні кодекси не містили окремої норми, яка би передбачала відповідальність за недбале зберігання вогнепальної зброї або бойових припасів.

Інше ставлення законодавця до визначення переліку суспільно небезпечних діянь у розглядуваній сфері спостерігається у КК УРСР 1960 року. У Главі X «Злочини проти громадської безпеки, громадського порядку та народного здоров'я» міститься три статті, в яких встановлюється відповідальність за незаконне носіння, виготовлення, зберігання та збут вогнепальної або холодної зброї чи вибухових речовин (ст. 222 КК), викрадення вогнепальної зброї, бойових припасів чи вибухових речовин (ст. $223 \mathrm{KK}$ ), необережне зберігання вогнепальної зброї та бойових припасів (ст. 224 КК) [17, с. 155-156].

На особливу увагу заслуговує напрям реформування, якого надалі зазнала стаття 222 КК УРСР 1960 р. 3 часу набуття КК УРСР 1960 р. чинності (з 1 квітня 1961р.) і до прийняття нового кримінального законодавства у 2001 р. стаття 222 КК «Незаконне носіння, виготовлення, зберігання та збут вогнепальної або холодної зброї чи вибухових речовин» зазнала змін. Передусім ці зміни стосувалися визначення та уточнення ознак об'єктивної сторони складу злочину. Зокрема, відповідно до змін закону в 1974 р. додатково кримінально караною визнається (окрім носіння, виготовлення, зберігання та збуту) придбання вогнепальної зброї, бойових припасів. До того ж законодавець уточнив сутність поняття «незаконне», додавши в ч. 1 ст. 222 КК словосполучення «без відповідного дозволу». Увесь цей час особливістю визначення законодавцем предмету злочину було те, що з усіх видів вогнепальної зброї виокремлювалася гладкоствольна мисливська зброя [18, с. 128]. 
На час набуття чинності Кримінальним кодексом (2001 р.) розглядувані нами положення містила ст. 263 КК «Незаконне поводження зі зброєю, бойовими припасами або вибуховими речовинами». Відтепер назва відповідної статті та зміст ії положень суттєво змінилися. По-перше, законодавець уперше використовує поняття «незаконне поводження», розглядаючи його як такі незаконні дії, які здійснюються без передбаченого законом дозволу. По-друге, об'єктивна сторона злочину, передбаченого ч. 1 ст. 263 КК, за переліком суспільно небезпечних дій вже охоплювала більшу сферу (порівняно з попереднім законом), оскільки полягала в носінні, зберіганні, придбанні, виготовленні, ремонті, передачі чи збуті вогнепальної зброї (крім гладкоствольної мисливської), бойових припасів, вибухових речовин або вибухових пристроїв без передбаченого законом дозволу (санкція передбачала позбавлення волі на строк від двох до п'яти років). Отже, додалися такі дії, як ремонт та передача відповідних предметів.

Далі на підставі виокремлення певних суспільно небезпечних дій (виготовлення, ремонт) та додавання до цих дій такого нового виду суспільно небезпечної поведінки, як переробка, в Кримінальному кодексі було визначено спеціальний склад злочину, передбачений ст. 263-1КК «Незаконне виготовлення, переробка чи ремонт вогнепальної зброї або незаконне виготовлення бойових припасів, вибухових речовин, вибухових пристроїв» (Закон № 5064-VI від 05.07.2012р.). Зазначені дії, з одного боку, охоплюються таким загальним поняттям, як «незаконне поводження» 3 вогнепальною зброєю, бойовими припасами, вибуховими речовинами або вибуховими пристроями, а з іншого боку, вони мали свою специфіку як дії, які безпосередньо спрямовані на створення, зміну, поліпшення їхніх властивостей, посилення ступеня їхньої небезпечності. У 2013 р. стаття 263-1 КК набула подальшого вдосконалення (Закон № 228- VII від 14.05. 2013 р.) за рахунок виокремлення нових видів суспільно небезпечної поведінки - фальсифікації, незаконного видалення чи зміни маркування вогнепальної зброї. А, відповідно, відтепер спеціальна кримінально-правова норма мала як нову назву, так і зміст ч. 1 ст. 263-1 КК: незаконне виготовлення, переробка чи ремонт вогнепальної зброї або фальсифікація, незаконне видалення чи зміна iii маркування, або незаконне виготовлення бойових припасів, вибухових речовин, вибухових пристроїв.
Зазначена вище інформація свідчить не лише про певні сталі тенденції довготривалого становлення кримінально-правових інститутів у сфері незаконного обігу зброї та бойових припасів, але підтверджує необхідність подовження процесу вдосконалення відповідного кримінального законодавства, зокрема положень, що $\epsilon$ в ст. 263-1 КК [7; 5, с. 122-123].

Висновки. Підсумовуючи зазначене, слід наголосити на такому. Правила обігу зброї з'явилися одночасно з появою і поширенням вогнепальної зброї. Відповідно, система злочинів проти громадської безпеки складалася протягом тривалого часу розвитку держави та права загалом. На підставі історико-правового аналізу нормативних актів, що регламентують незаконні дії зі зброєю, пропонується умовно виокремити певні історичні етапи.

X-XVI століття - етап становлення криміналізації діянь, пов'язаних із використанням зброї (різних іiі різновидів); діянь, предметом посягання яких $\epsilon$ зброя. У нормативно-правових положеннях часів Київської Русі та Галицько-Волинського князівства, що відтворювали сутність середньовічних джерел права, містилися диспозиції, що обмежували будь-які несанкціоновані діяння зі зброєю загалом або в певних конкретних ситуаціях, або щодо окремих осіб, визначали факт використання зброї як обставини, що значно обтяжують ступінь небезпечності діяння. Водночас громадська безпека ще не розглядається як самостійний об'єкт кримінально-правової охорони.

XVII - початок XX століття - етап формування кримінального законодавства щодо незаконного поводження зі зброєю та вибухівкою, переробки та інших дій, спрямованих на вдосконалення їхніх властивостей. Саме в цей період у Російській імперії сформувалася система нормативно-правових актів (як кримінально-правового характеру, так й іншого спрямування), що безпосередньо застосовувалася на території України або ж суттєво впливала на правозастосовну практику у сфері обігу зброї. Започатковується процес державного контролю за обігом зброї, який надалі посилювався. Сталою $€$ правова практика формулювання спеціальних правил користування (зберігання) зброї приватними особами, положень та правил щодо використання зброї в державних органах. Набувають подальшого уточнення положення щодо впливу на ступінь небезпечності діяння факту використання зброї як знаряддя злочину, так і тих ситуацій, коли зброя $\epsilon$ предметом правопорушень. 
У кримінально-правових джерелах (різні редакції Укладення про покарання кримінальні та виправні) вже міститься доволі значна кількість кримінально-правових норм, які ми можемо віднести до розглядуваної сфери (незаконний обіг зброї, бойових припасів, вибухових речовин). Проте містяться вони в різних розділах та главах, родовий об'єкт посягання яких $\epsilon$ різним (безпека держави, громадський спокій, право власності тощо). Найчастіше предметами незаконного обігу $\epsilon$ зброя, порох, бомби, гранати, снаряди до артилерійських знарядь тощо. А незаконність діянь по відношенню до цих предметів полягає в: різновидах незаконного виготовлення (саморобним способом або ж у заводських умовах); різновидах зберігання (взагалі, за межами певного місця, з перебільшенням певної кількості тощо); не донесенні відповідних відомостей; використанні в місцях масового скупчення людей; торгівлі тощо. Кваліфікуючою обтяжуючою ознакою щодо цих дій $\epsilon$ підрив державної безпеки чи спокою.

1920-1991 роки (переважно часи входження України до (РСР) - етап розвитку кримінального законодавства в частині уточнення дефініцій та санкцій щодо різних дій по відношенню до зброї, боєприпасів, вибухівки, змін їхніх властивостей. Особливості періоду чинності КК УРСР 1922 та 1927 рр. (порівняно $з$ попереднім етапом) полягають у суттєвому скороченні не лише кількості кримінально-караних діянь, які розглядаються як посягання на громадську безпеку та публічний порядок, але й відповідних кримінально-правових норм. Законодавець обрав шлях визначення в одній нормі декількох альтернативних дій (виготовлення, зберігання, купівля, збут), учинення хоч би однієї з них тягне кримінальну відповідальність, визначену в статті. Системно-правовий аналіз КK України 1922, 1927 та 1960 років доводить, що цей період характеризується інституціоналізацією розглядуваної сфери, виокремленням обігу зброї та бойових припасів у певний соціально-правовий деліктний феномен, суттєвим посиленням відповідальності за суспільно небезпечні діяння, що посягають на громадську безпеку, а отже, ті, що пов'язані з незаконним обігом зброї, бойових припасів та вибухових речовин.

З 1991 р. i дотепер - період остаточної трансформації та формування кримінального законодавства України у сфері незаконного обігу зброї, бойових припасів, вибухових речовин на тлі основних напрямів становлення правової незалежності України та обговорення можливо- стей легалізації обігу окремих видів зброї. Перелік альтернативних дій щодо незаконного обігу вогнепальної зброї бойових припасів, вибухових речовин або вибухових пристроїв (носіння, зберігання, придбання, виготовлення, ремонт, передача чи збут тощо) суттєво поповнився діями, які безпосередньо спрямовані на створення, зміну, поліпшення їхніх властивостей, посилення ступеня їх небезпечності. Отже, законодавець все більшу увагу приділяє криміналізації тих діянь, які пов'язані зі зміною властивостей вогнепальної зброї та бойових припасів.

\section{Література}

1. Боровинський С.Б. Витоки та сучасний стан кримінальної відповідальності за недбале зберігання вогнепальної зброї або бойових припасів. Науковий вісник Дніпропетровського державного університету внутрішніх справ. 2012. № 4. С. 412-419.

2. Георгиевский Э.В. История уголовного права России. Иркутск, 2004. С. 104.

3. Задоя А.А. Незаконный оборот оружия в дореволюционном праве Росии. История государства и права. 2011. № 16. С. 17-24.

4. Історія держави і права України : підручник для юрид. вищих навч. закл. / Ф.Й. Рогожин та ін. Київ : Інюре, 1996. Частина 1. 368 с.

5. Кримінальний кодекс України: чинне законодавство зі змінами та доповненнями на 17 липня 2020 року : Офіц. текст. Київ : Алерта, 2020. 224 с.

6. Меркулова В.О. Жінка як суб'єкт кримінальної відповідальності : монографія. Вид. 2-ге. Одеса : НДРВВ ОЮІ НУВС, 2003. 281 c.

7. Меркулова В.О., Катеренчук І.П. Незаконний обіг (незаконне поводження) зброї, бойових припасів або вибухових речовин: напрямки реформування кримінального законодавства. Південноукраїнський правничий часопис. 2017. № 3.

8. Мусаев М.М. Уголовная ответственность и наказание за незаконное изготовление оружия: исторический опыт и современные реалии. Проблемы в российском законодательстве. 2013. № 5. C. 155-159.

9. Невский С.А. Ответственность за незаконный оборот оружия по уголовному законодательству второй половины XIX - начала XX века. Уголовное право. 2003. № 2. С. 52.

10. Памятники русского права. Законодательные акты Петра I. Первая четверть XVIII века / под ред. К.А. Софроненко. Москва : Юрид. лит., 1961. Выпуск 8. С. 467-563.

11. Российское законодательство X-XX веков. Москва : Юрид. лит-ра, 1985. Том 2: Законодательство 


\section{Актуальні проблеми історико-правової науки}

периода образования и укрепления русского централизованного государства. С. 54-61.

12. Сошина Л.А. История развития уголовно-правовых норм, регламентирующих ответственность за незаконный оборот оружия в дореволюционный период России. Сибирский юридический вестник. 2008. № 2 (41). С. 103-107.

13. Уголовное уложение 22 марта 1903. Санкт-Петербург : Издание Н.С. Таганцева, 1904. 141 с.

14. Уложение о наказаниях уголовных и исправительных 1885 г. Изд. 16-е, пересмотр. и дополн. Санкт-Петербург : Издано Н.С. Таганцевым. 1912.

15. Уголовный кодекс УССР. Харьков : Юридическое издательство Наркомюста УССР, 1924. 75 с.

16. Уголовный кодекс УССР. Харьков : Юридическое издательство Наркомюста УССР, 1928. 79 с.

17. Уголовный кодекс Украинской ССР: Офиц. текст с изм. и допол. по состоянию на 1 июня 1983 г. Киев : Политиздат Украины, 1983. 215 с.
18. Уголовный кодекс Украины: Офиц. текст с изм. и допол. по состоянию на 31 октября 1996 г. Одесса : Издательство «Черноморье», 1996. 191 с.

19. Шалагин А.Е., Гребенкин М.Ю. Незаконный оборот оружия и его предупреждение. Вестник Казанского юридического института МВД Росии. 2017. № 2 (28). С. 55-60.

Меркулова В. О., доктор юридичних наук, професор, професор кафедри кримінального права та кримінології

Одеського державного університету внутрішніх справ

Павленко Л. М., аспірант Одеського державного університету внутрішніх справ 